\title{
Mesopotamian Women
}

Describing women as a separate topic of study has its problems. Women are not a "special issue," but form half of the population. Furthermore, we face the obvious problem of scope: Mesopotamia covers a huge area, over a period of three thousand years, and there was considerable variation in the roles of women within this geographical and chronological framework. Additionally, textual evidence from Mesopotamia is very uneven. Some areas and time periods are very well documented but there are also huge gaps. However, we can begin to fill in some of these gaps with information from the archaeological record and iconographic evidence.

Despite these challenges, we felt it was necessary to give the reader some basic background information regarding some of the most salient features in Mesopotamian women's lives. Thus, the following identifies some features of women's lives which were - in most places and times common denominators for them. In this chapter, we first outline women's position in society, followed by a discussion of women in and out of matrimony. Finally, elite women's lives in some specific periods and places are described. ${ }^{\mathrm{I}}$

I Several studies have been published regarding Mesopotamian women. In addition to those mentioned in the footnotes of this chapter, some of the most relevant and/or most recent volumes include: Mark Chavalas (ed.), Women in the Ancient Near East: A Sourcebook

(Routledge Sourcebooks for the Ancient World; London: Routledge, 20 I 4); Julia AsherGreve and Joan Goodnick Westenholz, Goddesses in Context (Göttingen: Vandenhoeck \& Ruprecht, 20I3); Simo Parpola and Robert Whiting (eds.), Sex and Gender in the Ancient Near East: Proceedings of the XLVIIe Rencontre Assyriologique Internationale, Helsinki, July 2-6, 2001 (Helsinki: The Neo-Assyrian Text Corpus Project, 2002); Zainab Bahrani, Women of Babylon: Gender and Representation in Mesopotamia (London: Routledge, 200I); Rivkah Harris, Gender and Aging in Mesopotamia: The Gilgamesh Epic and Other Ancient Literature (Norman, OK: University of Oklahoma Press, 2000); Susan Pollock, Ancient Mesopotamia: The Eden That Never Was (Case Studies in Early Societies; Cambridge: Cambridge University Press, I999); Barbara Lesko (ed.), Women's Earliest Records: From Ancient Egypt and Western Asia. Proceedings of the Conference on Women in the Ancient Near East, Brown University, Providence, Rhode Island, November 5-7, 1987 (Brown Judaic Studies I66; Atlanta, GA:

Scholars Press, I989); Jean-Marie Durand (ed.), La femme dans le Proche-Orient Antique: XXXIIIe Rencontre Assyriologique Internationale (Paris, 7-10 juillet 1986) (Éditions Recherche 


\section{I Social Classes and Legal Position}

On the whole, Mesopotamian society was divided into roughly three social classes: free, semi-free, and slaves. On one end of the continuum, the "free women" or "elite women" (Akkadian term awīlātum) were often mistresses of large households with servants and considerable economic responsibilities. On the other end were slaves. Slaves were owned by palaces, temples, and wealthy households. Throughout Mesopotamian history a varying percentage of the population was slaves. Some slaves were former free citizens who were forced into slavery by debts; some were war captives. A woman could be sold into slavery by her family, usually father or brothers, or even her husband. Another form of servitude was the pledging system in which a family member or a slave could be given to someone as a servant for a fixed term as a surety against a loan. If the borrower defaulted on the loan, the pledged person would then become the property of the individual providing the loan. In between elite women and female slaves (amätum) there was a class of semi-free or "subordinate" people in Mesopotamia, traditionally called muškennum in the law codes. Scholars have had some difficulties placing this class in society outside the framework of the law codes. Apparently they were tied to their masters or the owners of the land that they cultivated but they were definitely not slaves. ${ }^{2}$

Very little is known about the lives of slave women or the women of the muškeenum-class, since written evidence mostly deals with the affairs of the wealthy. One needed resources to learn how to read and write or even to hire a scribe. Therefore, their voices are rarely preserved within the texts from Mesopotamia. Poor and slave women mainly appear within texts only as objects of trade.

Throughout Mesopotamian history women had the right to conduct legal transactions. They engaged in trade, lending and borrowing, and acquired property. It is very difficult to assess how freely they could do this. On the whole, women were probably under the jurisdiction of the male head of the family except for widows and some other special cases. However, this did not necessarily mean that they needed explicit male consent for every act. This is

sur les Civilisations; Paris: CNRS, I987); and Averil Cameron and Amélie Kuhrt (eds.), Images of Women in Antiquity (London \& Canberra: Croom Helm, I983). Additionally, see NIN: Journal of Gender Studies in Antiquity (four issues, from 2000 to 2003).

2 See Samuel Greengus, "Legal and Social Institutions of Ancient Mesopotamia," in Civilizations of the Ancient Near East (ed. Jack Sasson; New York: Simon \& Schuster, I994), 469-484, esp. 475-478; Amélie Kuhrt, "Non-Royal Women in the Late Babylonian Period: A Survey," in Women's Earliest Records: From Ancient Egypt and Western Asia (ed. Barbara Lesko; Brown Judaic Studies I66; Atlanta, GA: Scholars Press, I989), 2 I 5-239, esp. 230-235; and J. N. Postgate, Early Mesopotamia: Society and Economy at the Dawn of History (London: Routledge, I994), 237-240. 
particularly true for wealthy women, who had the means and status to act on their own. ${ }^{3}$

\subsection{Marriage}

Marriage was the common denominator for most individuals. In general, all men and women were expected to marry and have children. A woman lived with her family under the authority of her father until she married. Marriages were usually arranged by the fathers of the bride and the groom. Often the bride was considerably younger than the groom. Both fathers gave contributions for the new household: a dowry was supplied by the father of the bride and the family of the groom provided bride wealth. The marriage was completed in stages, possibly with a long engagement period. The marriage was finalized when the bride and groom moved in together. The aim of any marriage was to produce male heirs who would then take care of their parents when they aged. Divorce was not common but did happen in some cases. A husband could send his wife away and pay her compensation but it was a far more serious matter for a woman to leave her husband. Worst-case scenarios could include the wife being condemned to death through drowning or thrown off a tower, or she could be sold into slavery. A man could take a second wife in a few special circumstances (e.g., if the first one did not provide him with children) but women were never allowed to take more than one husband. ${ }^{4}$

All through Mesopotamian history people acted as members of a family, a clan, or an institutional household (bitum, lit. "house"). Women could work, for example, in the royal household, a governor's estate, or a temple. Often we know very little about the lives of women outside these institutions. Some of them might have joined these households while simultaneously keeping up their own families, while others might have dedicated

3 Greengus, "Legal and Social Institutions of Ancient Mesopotamia," 479; Kuhrt, "NonRoyal Women," 228-230; and Rivkah Harris, "Independent Women in Ancient Mesopotamia?" in Women's Earliest Records, I45-I 56 esp. I46-I49. For women and law, see Elisabeth Meier Tetlow, Women, Crime, and Punishment in Ancient Law and Society, vol. I: The Ancient Near East (New York: Continuum, 2004) and Sophie Lafont, Femmes, droit et justice dans l'antiquité orientale: Contribution à l'étude du droit pénal au Proche-Orient ancien (Orbis Biblicus et Orientalis I65; Freiburg: Universitätsverlag / Göttingen: Vandenhoeck \& Ruprecht, I999).

4 See Postgate, Early Mesopotamia, 88-108; Greengus, "Legal and Social Institutions of Ancient Mesopotamia," 478-48 I; Marten Stol, "Private Life in Ancient Mesopotamia," in Civilizations of the Ancient Near East, 485-50 ; Marten Stol, "Women in Mesopotamia," Journal of the Economic and Social History of the Orient 38, no. 2/4 (I995): I23-I44; Kuhrt, "Non-Royal Women," esp. 225-228; and Martha Roth, "Marriage and Matrimonial Prestations in First Millennium B.C. Babylonia," in Women's Earliest Records, 245-344. 
their lives to serving the institution, seeing their service as an alternative to marriage and children. ${ }^{5}$

Temples and palaces employed women as musicians, scribes, administrative personnel, and cultic professionals. In some cases these women lived in the palace or temple, but in many cases it would have been quite possible for them to have a house, a husband, and children elsewhere. The compensation they received for their work varied considerably. Many received food, clothing, and other items according to their rank as members of the institutional household. For example, the female administrators (šakintu) in the Neo-Assyrian palaces were wealthy and influential. Considering their extensive responsibilities in the palace, they may have lived there as well. ${ }^{6}$

At the other end to the professionals were the less fortunate women. In the early Sumerian institutions, and probably later as well, women formed a large work-force for physically demanding labor. They worked as weavers, ground flour, towed boats, and cut reeds. Apparently they received for their work half of the rations given to male workers. Women are also known to have worked as midwives, nurses, and tavern keepers. ${ }^{7}$

There were also groups of women who lived outside matrimony. This did not mean that they were independent, at least not in the modern, individualistic sense of the word. Most of them still belonged to a family or an institutional household. The extent of this belonging had great influence on their position.

Widows formed the largest group of women living outside matrimony. They were by no means a monolithic group. In the law codes widows and orphans were often portrayed as being especially vulnerable and in need of the king's special attention. Yet not all widows were economically vulnerable. For instance, a widow with under-age children could take control of her deceased husband's business and property and manage it until her son came of age. If there were no children and her father was still alive, the widow could also return to the house of her father. The widow did not usually inherit her husband's property, but she would keep her own possessions if her husband died. Such property could include her dowry as well as other gifts from her family. The main inheritance share regularly went to the eldest son. Other sons received smaller amounts. Unmarried daughters received a dowry from the estate, which functioned as a woman's inheritance share. The sons were expected to care for their mother in her old age. Thus a widow with enough property of her own could act fairly autonomously, whereas a poor widow without sons or male relatives to care for her

5 Most evidence for this comes from temples; see, e.g., on nadìtum women (2.3 "Elite women").

6 Saana Svärd, Women and Power in Neo-Assyrian Palaces (SAAS 23; Helsinki: The NeoAssyrian Text Corpus Project, 2015), 9I-IO5.

7 Marc Van de Mieroop, "Women in the Economy of Sumer," in Women's Earliest Records, 53-66, esp. 63-66; and Stol, "Women in Mesopotamia," I 37. 
would have been in a difficult position. Remarriage was often an option and the procedure for remarriage did not necessarily involve all the stages of the first marriage. ${ }^{8}$

Additionally, prostitutes lived outside matrimony and apparently also without institutional affiliations. The general consensus among Assyriologists is that the Akkadian word for a prostitute was harimtu, although Julia Assante has suggested that harimtu did not actually refer to "a prostitute" but rather to "a single woman." According to her, the main qualification for harimtu is that she was neither "a wife of a man" nor "a daughter of a man," i.e. she did not belong to a household with a male head of the family. Whether or not the harimtu women were prostitutes, it seems that they too could be either rich and autonomous or, on the other hand, little more than slaves. Some of them probably owned the income they made and could have been rather independent in that sense. ${ }^{9}$

The eminent scholar Amélie Kuhrt has convincingly argued that women who had escaped regular masculine authority were considered dangerous for social order and even possible sources of evil witchcraft. Witchcraft was taken extremely seriously by Mesopotamians. People were believed to be vulnerable to all kinds of attacks by magical means. Misfortune which was caused by sorcery needed to be dispelled by a specialist who used "white magic" to counter the evil intent of the sorcerer. For the most part, sorcery was seen as a weapon of women, although male sorcerers are occasionally mentioned. ${ }^{\text {Io }}$

\subsection{Elite Women}

Elite women are far better represented in the textual record than poor women. The most prominent elite institutions of Mesopotamia were the palace and the temple. Women could have considerable authority in both institutions. They served as heads of temples and on rare occasions as ruling queens. ${ }^{\text {I I }}$ The lives of

8 Stol, "Women in Mesopotamia," esp. I32-I34.

9 Julia Assante, "The kar.kid/harimtu, Prostitute or Single Woman? A Reconsideration of the Evidence," Ugarit-Forschungen 30 (I998): 5-96, esp. 8-I3; Jerrold Cooper,

"Prostitution," Reallexikon der Assyriologie I I, no. I/2 (2006): I 3-2 I; and Harris, "Independent Women in Ancient Mesopotamia?," esp. I49.

Io Kuhrt, "Non-Royal Women," esp. 238. For witchcraft see, e.g., Karel Van Der Toorn, From her Cradle to her Grave: The Role of Religion in the Life of the Israelite and the Babylonian Woman (trans. Sara Denning-Bolle; Sheffield: JSOT Press, I994), esp. I I 3-I I6; and Yitschak Sefati and Jacob Klein, "The Role of Women in Mesopotamian Witchcraft," in Sex and Gender in the Ancient Near East, 569-587; and Tzvi Abusch, Mesopotamian Witchcraft: Toward a History and Understanding of Babylonian Witchcraft Beliefs and Literature (Ancient Magic and Divination 5; Leiden: Brill-Styx, 2002).

I I Debate on this is ongoing: see Kathleen McCaffrey, "The Female Kings of Ur," in Gender through Time in the Ancient Near East (ed. Diane Bolger; Gender and Archaeology I7; Lanham: AltaMira Press, 2008), I73-2I 5. 
such women are occasionally very well known. The following five groups of women are especially well documented: the royal women of the Ur III kingdom (ca. 21 I2-2004), Old Assyrian merchant women (ca. I900-I830), Old Babylonian naditum-women (ca. I880-I550), palace women of the Old Babylonian city-state of Mari (ca. I8IO-I760), and the elite women of the Neo-Assyrian Empire (ca. 900-6I2). A short introduction is given here on these "clusters." More specific details can be found in the introductions to the texts.

The Sumerian third dynasty of Ur (Ur III) in southern Mesopotamia is known from more than IO0,000 texts, most of which relate to the economy and administration of the realm. These documents show that women were participating in sanctioned power within all levels of society and formed an essential part of administrative structures of the kingdom. The queen and other high-ranking royal women had important duties in the palace and the cult. The household of the queen was a large and influential institution. The wives of many governors were also active figures. Especially well documented is women's involvement in textile production. ${ }^{12}$ In this anthology the "Lullaby for a Son of Šulgi" (5.3.3) possibly originates from the Ur III period.

Most documents from the Old Assyrian period come from the trading colony in Kanesh in Anatolia, where the Assyrians had a permanent trading outpost, a kārum. Archaeologists have excavated a large number of cuneiform tablets recording lively correspondence between the men in karum Kanesh and the women of the family who had stayed in the capital of the kingdom, Assur, over I, Ioo km to the south. The trade mostly consisted of shipments of tin and textiles via donkey caravans to Kanesh, and silver and gold flowing back to Assur. The women sending textiles to Kanesh were actively engaged in the family's trading enterprises. ${ }^{\mathrm{I}}$ Some letters sent by these women are included in 6.2.

Much of the evidence from the Old Babylonian period regarding elite women relates to the naditum-women. The priestesses were dedicated to a

I2 Rita Wright, "Gendered Relations and the Ur III Dynasty: Kinship, Property, and Labor," in Gender through Time in the Ancient Near East, 247-279 and Van de Mieroop, "Women in the Economy of Sumer," esp. 57-63. Cf. Frauke Weiershäuser, Die königlichen Frauen der III. Dynastie von Ur (Göttinger Beiträge zum Alten Orient I; Göttingen: Universitätsverlag, 2008) and Weiershäuser, "Die bildliche Darstellung königlicher Frauen der III. Dynastie von Ur und ihre sozialpolitische Aussage," in Images and Gender: Contributions to the Hermeneutics of Reading Ancient Art (ed. Silvia Schroer; Orbis Biblicus et Orientalis 220; Göttingen: Academic Press Fribourg, 2006), 263-279.

I 3 Amélie Kuhrt, "The Old Assyrian Merchants," in Trade, Traders and the Ancient City (ed. Helen Parkins and Christopher Smith; London: Routledge, 2005), i 5-30. Cf. Elizabeth Wayland Barber, Women's Work: The First 20,000 years; Women, Cloth, and Society in Early Times (New York: W. W. Norton \& Company, I994), I64-84 and Klaas Veenhof, Aspects of Old Assyrian Trade and its Terminology (Studia et Documenta ad iura Orientis Antiqui Pertinentia Io; Leiden: Brill, I972). 
male god: to Šamaš in the city of Sippar, to Marduk in Babylon, and to Ninurta in Nippur. In Sippar they lived within the gagûm-building complex, which is often translated as a "cloister." "Cloister" is not the best translation as these women were definitely not cut off from the world or only concentrating on religious matters, although the initiation to the temple resembled marriage. Mainly the term "cloister" has been used because these women did not bear children. Instead, they could give their husbands secondary wives to bear descendants. Most of our information comes from Sippar, which means that it does not necessarily reflect the lives of the naditum-women in other cities.

At least in Sippar, the naditum were wealthy women, often daughters of elite families. They were engaged actively in financial transactions, agricultural production as well as cultic duties. Some of them could even read and write. It seems that they were entitled to clothing, food, and oil from their families. There is evidence that after her death a naditum-woman's property was inherited by her male relatives, but in some cases she could also will it to an outsider, for example to a slave or a younger naditum whom she had adopted to take care of her in her old age. ${ }^{14}$

The Old Babylonian qadištum and kulmašitum-women, who also appear in the current volume, belonged to the same general class of women as the naditum, although there is less textual evidence regarding them. The titles were connected to cult and these women could own property, like naditumwomen. However, unlike the naditum, they could marry and have children. Apparently the qadistum had something to do with babies, in delivering them and/or wet-nursing them. There is some circumstantial evidence to suggest that a qadistum might have been literate (see chapter 4). Furthermore, the qadištum and kulmašitum appear in the Old Babylonian letters of the naditum (chapter 6). ${ }^{\text {IS }}$

Another remarkable Old Babylonian source regarding women are the texts from the city of Mari, which was located in western Mesopotamia on the bank of the Euphrates. The texts found there mostly originate from a very short time period, from the reigns of two kings (ca. I790-I745). Thousands of clay tablets have been excavated from the royal palace of Mari and they illuminate all aspects of administration and palace business during those years. It is clear that women were an integral part of state administration in Mari. When the king was away it seems that his queen even

I4 Ulla Jeyes, "The Nadītu Women of Sippar," in Images of Women in Antiquity (ed. Averil Cameron and Amélie Kuhrt; London \& Canberra: Croom Helm, I983), 260-72 and Harris, "Independent Women in Ancient Mesopotamia?," esp. I 54-56. Cf. Elizabeth Stone, "The Social Role of the Naditu Women in Old Babylonian Nippur," Journal of the Economic and Social History of the Orient 25, no. I (1982): 50-70.

I 5 Joan Goodnick Westenholz, "Tamar, qedēša, qadištu, and Sacred Prostitution in Mesopotamia," Harvard Theological Review 82/3 (I989): 245-265. See also CAD s.v. qadištu and kulmašìtu. 
acted as a vicegerent. Secondary wives and other high-ranking women - such as the governor's wife - played significant roles as well. They organized cultic matters, sent oracles to the king, and took care of the smooth running of economic activities, for example textile production. ${ }^{\mathrm{I} 6} \mathrm{We}$ have included some letters sent by the women of the royal palace at Mari (chapter 6) as well as some very interesting oracles delivered by female prophets who were located near there (chapter 8).

Neo-Assyrian women are also very well attested. The Neo-Assyrian Empire was huge, covering Mesopotamia from the Persian Gulf to the Mediterranean, and even parts of Egypt at times. Thousands of NeoAssyrian cuneiform tablets have been found - mostly from royal palaces but also some temple and private archives are known. Regarding the royal women, we have numerous administrative deeds and documents, as well as letters, dedications and inscriptions. Neo-Assyrian queens clearly wielded considerable influence. As in previous times, their households were an integral part of the administration of the state. Some left such a lasting impression within cultural memories that their names were transmitted to the Greeks. ${ }^{\text {I7 }}$

In addition to queens and the female relatives of the king, also the "court women" (sekretu) lived in the palaces. There were many women working there as well, especially in the administration of the queen's household. There is some evidence that the queen's household might have been involved in large-scale textile production. Moreover, female musicians were employed in large numbers in Neo-Assyrian palaces. ${ }^{\text {I }}$ The NeoAssyrian temples are not as well known as temples in some previous periods, but prophets played a prominent role in Neo-Assyrian society and several extant oracles were delivered by female prophets. ${ }^{\text {I9 }}$ In this

I6 B.F. Batto, Studies on Women at Mari (Baltimore: Johns Hopkins University Press, I974). Cf. Nele Ziegler, Florilegium Marianum IV: La population féminine des palais d'apres les Archives Royales de Mari: Le harem de Zimrî-Lîm (Mémoires de NABU 5; Paris: SÉPOA, I999).

I7 Some of their memories are clearly exaggerated or mythologized but this does not detract from fact that these women were tremendously influential in their lifetime and that their reputations were embedded within the traditions of Mesopotamia and beyond (Gerald P. Verbrugghe and John M. Wickersham, Berossos and Manetho [Ann Arbor: University of Michigan Press, 200I], 2 I-22).

I 8 For Neo-Assyrian musicians, see Sherry Lou Macgregor, Beyond Hearth and Home: Women in the Public Sphere in Neo-Assyrian Society (SAAS 21; Helsinki: The Neo-Assyrian Text Corpus Project, 20I2), 29-54. Note that their role in palaces seems to have been quite different from the role of female musicians in Old Babylonian Mari (Nele Ziegler, Florilegium marianum IX: Les musiciens et la musique d'après les archives de Mari [Mémoires de N.A.B.U. I0; Paris: SEPOA, 2007], $3 \mathrm{I}-48$ ).

I9 On Neo-Assyrian women, see Macgregor, Beyond Hearth and Home: Women in the Public Sphere in Neo-Assyrian Society; Saana Svärd, Women and Power in Neo-Assyrian Palaces (SAAS 23; Helsinki: The Neo-Assyrian Text Corpus Project, 20I5) and Sarah Melville, The Role of 
anthology we have included letters by palace women (6.7), some inscriptions by Neo-Assyrian queens (chapter 7), the Zakûtu treaty (9.2.I), and prophetic oracles (chapter 8 ).

On the whole, the Mesopotamian evidence suggests that elite women acted in all the roles that men did, although considerably fewer women than men appear in writing from Mesopotamia. Women corresponded with men, with the king, with each other, bought, sold, loaned, borrowed, guaranteed debts and acted as witnesses, owned property, were involved in trading ventures, used seals, etc.

Naqia/Zakutu in Sargonid Politics (SAAS 9; Helsinki: Neo-Assyrian Text Corpus Project, I999). On the female prophets, see Martti Nissinen, "The Socioreligious Role of the Neo-Assyrian Prophets" in Prophecy in its Ancient Near Eastern Context: Mesopotamian, Biblical and Arabian Perspectives (ed. Martti Nissinen; Society of Biblical Literature Symposium Series 13; Atlanta: SBL, 2000), 89-I I4. 